UDC $553.4(571.56)$

\title{
The Kis-Kuel Fe-Cu-Au $\pm(\mathrm{Ag}, \mathrm{Mo}, \mathrm{Bi})$ Deposit, Eastern Yakutia (Russia) - A Link between Iron Oxide Copper-Gold and Intrusion-Related Gold Systems
}

\section{A. V.Kostin}

Diamond and Precious Metal Geology Institute, Siberian Branch, Russian Academy of Sciences, 39, ul. Lenina, Yakutsk, 677000, Russian Federation

For citation: Kostin, A. V. (2019). The Kis-Kuel Fe-Cu-Au $\pm(\mathrm{Ag}, \mathrm{Mo}, \mathrm{Bi})$ Deposit, Eastern Yakutia (Russia) - A Link between Iron Oxide Copper-Gold and Intrusion Related Gold Systems. Vestnik of Saint Petersburg University. Earth Sciences, 64 (4), 516-529. https://doi.org/10.21638/spbu07.2019.401

The iron oxide copper-gold (IOCG) deposit class includes a number of loosely related deposits with a pool of common characteristics. The Kis-Kuel intrusion-related IOCG deposit in Eastern Yakutia (Russia) with a wide range of mineral styles has a direct genetic link with a cooling intrusion during its formation. The IOCG and the Kis-Kuel have common features for this style-an abundance of iron oxides and a low presence of sulfides. Magmatic contribution to the Kis-Kuel deposit is significant. Intrusive rocks range from diorite to granodiorite in composition. The rare-earth geochemical system of igneous rocks of the Kis-Kuel intrusion is characterized by behavior close to the CHArge-and-RAdius-Controlled CHARAC-system $(26<\mathrm{Zr} / \mathrm{Hf}<46$ and $24<\mathrm{Y} / \mathrm{Ho}<34)$ in which the $\mathrm{H} / \mathrm{Ho}-\mathrm{Zr} / \mathrm{Hf}$ ratios of the pair show a distribution close to chondrite $(\mathrm{Zr} / \mathrm{Hf}-36.6$ and $\mathrm{Y} / \mathrm{Ho}-27.7)$. Minor deviations of the Kis-Kuel rocks from CHARAC intervals indicate an unevolved magmatic system. Mineralization was discovered at the top of the small Kis-Kuel pluton and includes several types of ore. Iron oxide copper-gold and $\mathrm{Cu}-\mathrm{Au}$ porphyry ore are present as breccia in hornfels aureole of intrusive rocks with FeOX - 13.5863.24\%; $\mathrm{Cu}-0-3.57 \%$; $\mathrm{Au}-12.93-64.48 \mathrm{~g} / \mathrm{t} ; \mathrm{Ag}-2.7-830 \mathrm{~g} / \mathrm{t}$. Associated with IOCG, quartzhematite-galena veins contain: $\mathrm{Ag}-22.4-3680 \mathrm{~g} / \mathrm{t} ; \mathrm{Cu}-0.014-0.534 \% ; \mathrm{Pb}-0.1-81.63 \%$. Arrays of sheeted auriferous quartz veins with arsenopyrite, native gold and bismuth and Ag-Bi sulphosalts contain: $\mathrm{Au}-0.15-4.6 \mathrm{~g} / \mathrm{t} ; \mathrm{Ag}-20.6-196 \mathrm{~g} / \mathrm{t} ; \mathrm{Cu}-0.048-0.24 \% ; \mathrm{Pb}-0.3-3.73 \%$. This paper is devoted to a Kis-Kuel diorite-granodiorite-related deposit in Eastern Yakutia (Russia). It is regarded as an intrusion-related gold deposit (IRGD) with a main IOCG and minor $\mathrm{Cu}$-Au-porphyry component of mineralization.

Keywords: Eastern Yakutia, Kis-Kuel ore cluster, iron oxide copper-gold deposit, intrusion-related, gold prospecting.

\section{Introduction}

Iron oxide copper-gold (IOCG) deposits have received considerable exploration attention worldwide due to the attractive size and grade of gold. Deposits are characterized

(C) Санкт-Петербургский государственный университет, 2019 
by having more than $20 \%$ iron oxide content and low sulphides within the ore zones. This deposit style is still undiscovered in the Russian Far East (Fig. 1).

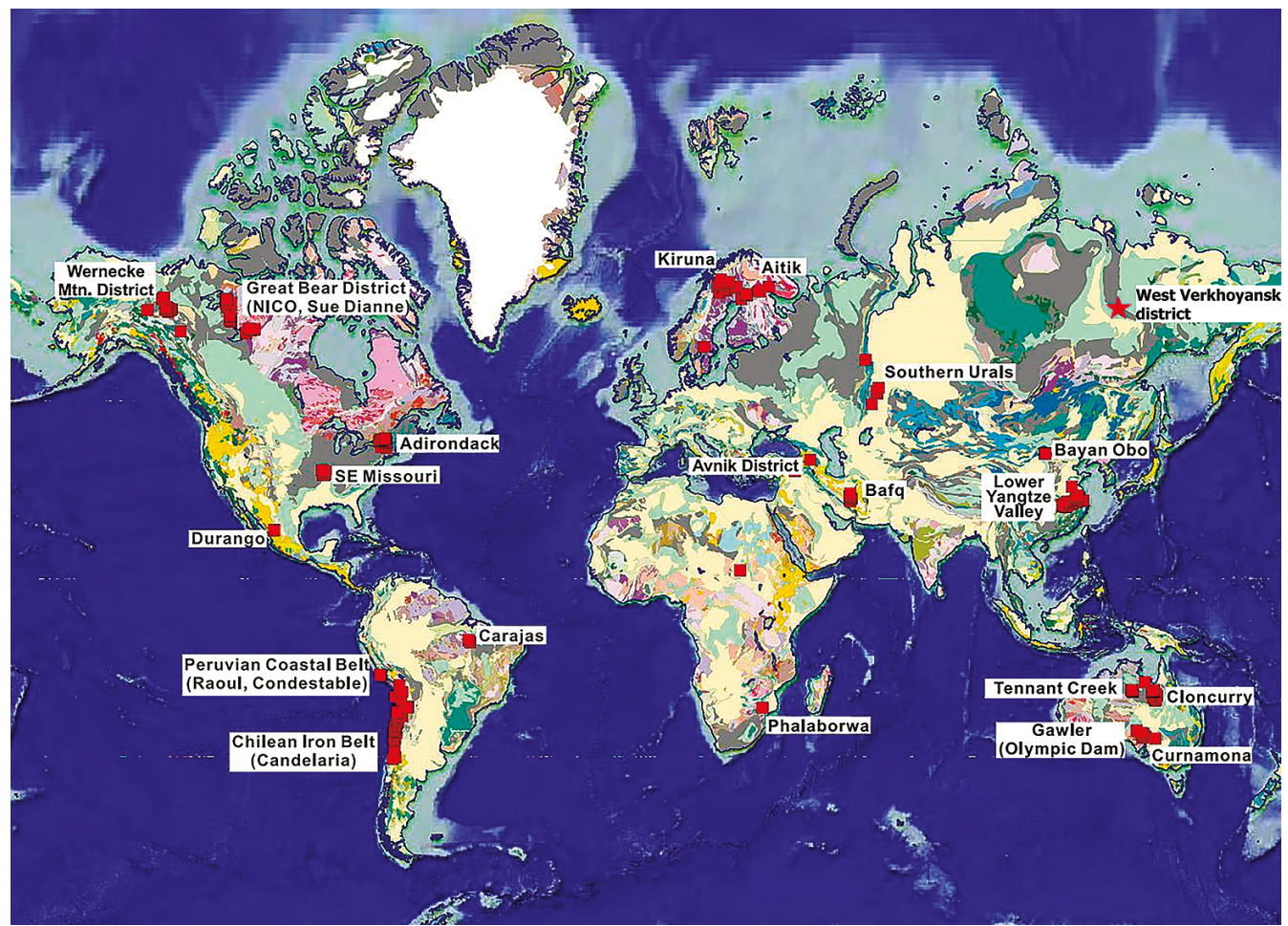

Fig. 1. Distribution of IOCG deposits and districts (red squares) modified from Williams et al. (2005), Corriveau (2007) and Corriveau et al. (2018) and references therein - presented on a geological map of the world base from Chorlton (2007); the star shows the location of the the Kis-Kuel IOCG deposit. Australia: Gawler district (Olympic Dam, Acropolis, Moonta, Oak Dam, Prominent Hill and Wirrda Well), Cloncurry district (Ernest Henry, Eloise, Mount Elliot, Osborne and Starra), Curnamona district (North Portia and $\mathrm{Cu}$ Blow), Tennant Creek district (Gecko, Peko/Juno and Warrego). Brazil: Carajas district (Cristalino, Alemao/Igarapé Bahia, Salobo and Sossego). Canada: Great Bear Magmatic Zone (Sue-Dianne and NICO), Wernecke district (West Coast skarns), Central Mineral Belt district and Kwyjibo deposit. Chile: Chilean Iron Belt district (Candelaria, El Algarrobo, El Romeral, Manto Verde and Punta del Cobre). China: Bayan Obo (Inner Mongolia), Middle Lower Yangtze Valley district (Meishanand Daye). Iran: Bafq district (Chogust, Chadoo Malu, She Chahoon). Mauritania: Akjoujt deposit. Mexico: Durango district (Cerro de Mercado). Peru: Peruvian Coastal Belt (Raul, Condestable, Eliana, Monterrosas and Marcona). Sweden: Kiruna district (Kiirunavaara, Loussavaara), Aitik deposit (also described as a porphyry Cu deposit). South Africa: Phalaborwa and Vergenoeg deposits. USA: Southeast Missouri district (Pea Ridge and Pilot Knob); Adirondack and MidAtlantic Iron Belt (Reading Prong). Zambia: Shimyoka, Kantonga, and Kitumba. Russian Federation: West Verkhoyansk district (Kis-Kuel)

The Kis-Kuel IOCG site is located in the West Verkhoyansk plutonic arc of the Late Cretaceous age and is closely related to a reduced intrusive complex of diorite-granodiorite. Its deposit morphology is separated into several styles: veins and hydrothermal breccias, arrays of sheeted auriferous quartz veins hosted by intrusive rocks and stockwork in the intrusive exocontact zone. After T.M.Porter (2000), we think that the iron oxides at Kis-Kuel may be an early evolutionary phase of a hydrothermal event, as at the Olympic Dam and other IOCG deposits. 
In Eastern Yakutia, many deposits, including intrusion-related, contain a significant amount of silver and copper. An audit of ore collection samples from the Kis-Kuel intrusive area and fieldwork in 2018 allowed the identification of intrusion-related IOCG ores. Mineralization in the Kis-Kuel pluton includes several types of ores: iron oxide coppergold; quartz-hematite-galena veins associated with IOCG; brecciated sandstone with Feoxide-galena-quartz cement in the exocontact zone; arrays of sheeted auriferous quartz veins with arsenopyrite, native gold and bismuth and Ag-Bi sulphosalts. The deposit belongs to the combined type, in which gold-copper-porphyry and IOCG ores are genetically linked and located inside the diorite-granodiorite intrusive body.

Within one pluton IOCG and porphyry $\mathrm{Cu}-\mathrm{Au}$ mineralization form complex ore bodies with similar geochemical and mineralogical features. This was discovered in Cloncurry district (Australia) by Pollard (2000), who showed that intrusive rocks linked to IOCG deposits are similar to intrusive rocks linked to porphyry $\mathrm{Cu}$ - $\mathrm{Au}$ deposits with the key role of magmatic-hydrothermal fluids in deposit formation. More recently, the relationship between IOCG and porphyry deposit types has been well established in northern Chile (Richards et al., 2017).

\section{Materials and Methods}

During 2009 and 2018 fieldwork, 29 representative surface samples of igneous rocks and 97 grab samples of different ore styles were collected. All chemical analyses of intrusive rocks were carried out at the Diamond and Precious Metal Geology Institute, Siberian Branch, Russian Academy of Sciences (DPMGI SB RAS). The major element compositions were analyzed using methods of spectrometry, atomic emission spectrometry, ionometry with ion-selective electrode, gravimetry and titrimetry. Trace elements were analyzed by inductively coupled plasma mass spectrometry (ICP MS) in the chemical analytical center Plasma in Tomsk, Russia.

For ore samples, the mass fraction of iron oxide (total) and mass fraction of iron were determined by the photometric method on spectrophotometer SF-56. Grades of gold (g/t), silver (g/t) and copper (\%) were determined by the atomic absorption method on the iCE 3500 spectrometer. The standards used with ore samples analysis include GBM906-6 GEOSTATS PTY LTD: Ag - 389.7 g/t and G908-8 - GEOSTATS PTY LTD: Au - 9.65 g/t.

Ore minerals were identified by scanning electron microscope JSM-6480LV with energy spectrometer INCA-Energy, accelerating voltage at the cathode $20 \mathrm{kV}$. Samples were prepared from polished sections with a sprayed thin conductive layer of carbon. Minerals in strongly oxidized ores were determined by x-ray phase analysis using D2 PHASER diffractometer. All microprobe and x-ray analyses were carried out in DPMGI SB RAS.

Before 2008, the Kis-Kuel area was known as a "greenfield" with no mineral potential. In 2008-2009, detailed field studies, including geological mapping and gold and silver ore prospecting, were conducted at the Kis-Kuel area. It became clear that it has a good potential for lode silver and gold deposits, and in 2018, about 10 new ore veins were discovered.

SAT images are a good instrument for discovering the presence of elevated concentrations of iron oxides nearby. Large magmatic systems with IOCG potential may have three types of Fe-oxide mineralization - directly at the contacts with the intrusive rocks (bright yellow shades), in hornfels zone (dark brown), and along the edge of plutons (dark yellow and brown tints) (Kostin, 2012; Kostin et al., 2014). Field observations showed that 
dark yellow and brown tints on SAT images highly corresponded to IOCG mineralization. SAT images of Ikonos and Microsoft Bing Maps were used during fieldwork to compile a geological map of the Kis-Kuel site (Fig. 2).

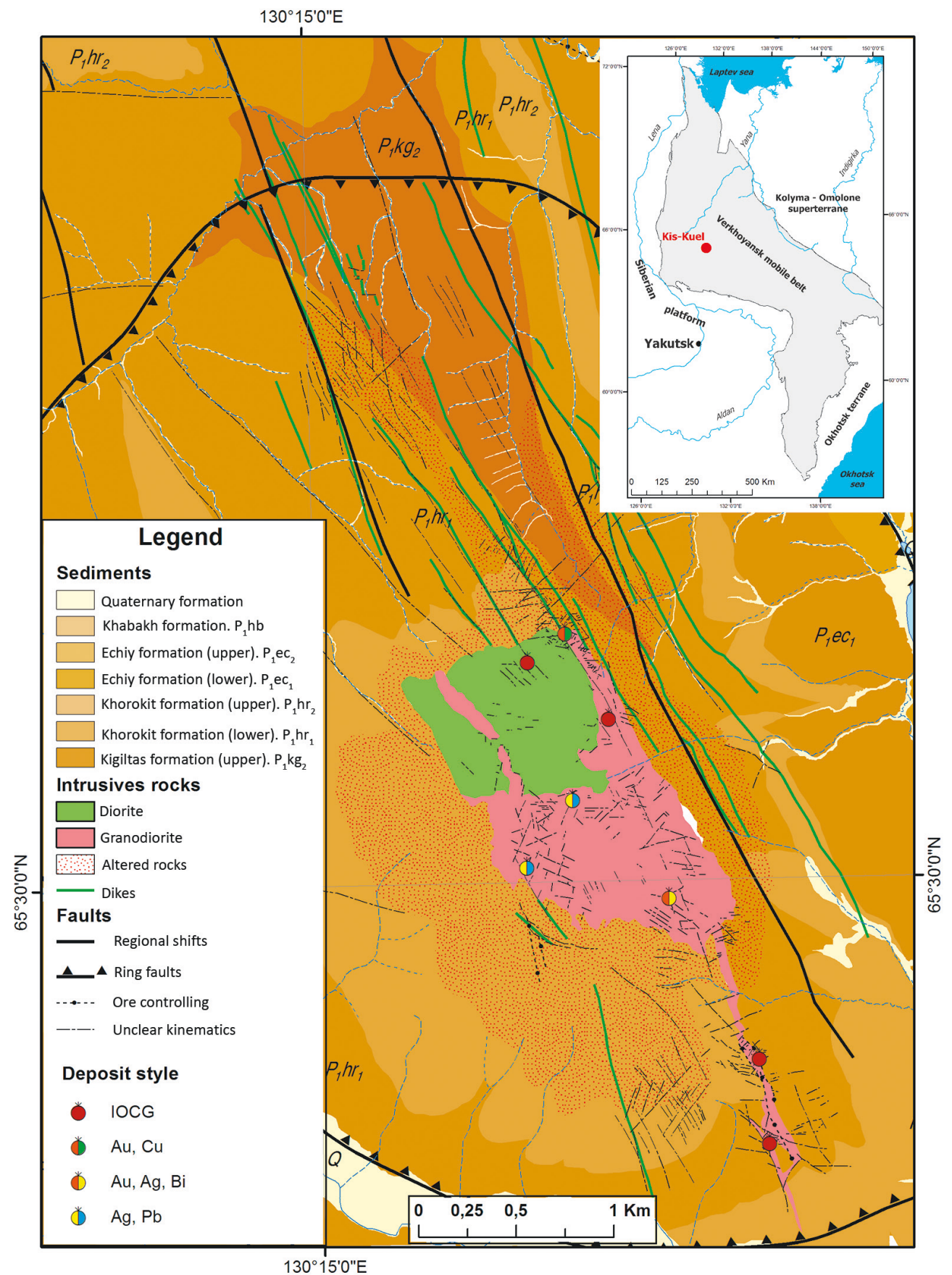

Fig. 2. Geological map of the Kis-Kuel site and occurrences of the main ore styles showing all of discovered ore mineralization intside the Kis-Kuel intrusive. The red dot on the inset map shows the position of the ore cluster in the Verkhoyansk Range 
The site is located in the year-round permafrost climate zone. Widely spread permafrost heaving on the root surface of the Kis-Kuel intrusive body destroys ore veins and lifts heavy pieces of galena and iron oxides up to the surface. It is the main prospecting feature for all ore types. Another one is malachite and azurite in thin fractures in diorites, usually located near or in IOCG ores (Supplement $1.1^{1}$ ).

\section{Geological setting and ore control of the Kis-Kuel ore cluster}

The Verkhoyansk fold-and-thrust belt borders the eastern margin of the Siberian platform for $2000 \mathrm{~km}$, from the Arctic Ocean to the Sea of Okhotsk, and is up to $500 \mathrm{~km}$ in cross-sectional width. The research area is located in its central part and accommodates a large silver and gold province among Carboniferous and Permian clastic sediments with many mineral deposits. The most significant of them are Kysiltassky, Arkachansky and Kis-Kuelsky gold \pm silver deposits and Vertikalny, Mangazeysky, Prognoz, Kimpichensky and Khachakchansky silver deposits (Kostin et al., 1997a; Kostin et al., 1997b; Kostin, 2002; 2003). This article provides the first evidence of IOCG-style mineralization in this region, at Kis-Kuel, which previously had been considered a greenfield area.

The Kis-Kuel area is located within the Verkhoyansk mobile belt of northeastern Yakutia. According to Parfenov et al. (Tectonics..., 2001) and Nokleberg et al. (Metallogenesis..., 2010), the fold-and-thrust belt forms part of a major orogenic system separating the Siberian North Asian Craton to the west from the immense expanse of accreted terrains, which form most of the Russian Far East. The belt extends for $2000 \mathrm{~km}$ from the Laptev Sea to the Sea of Okhotsk and is made up of Late Precambrian to Triassic rocks, deposited along the paleo-Pacific margin of the Siberian Craton. According to Prokopiev et al. (2016), this margin was developed due to rifting events which occurred in the Late Precambrian and again during the Late Devonian to Early Mississippian periods. Deformation events during the Late Jurassic to Early Cretaceous periods were accompanied by low-grade metamorphism in the internal parts of the belt and the emplacement of granitic plutons (Parfenov et al., 1995). During the Tertiary period, strike-slip faulting occurred within the fold-and-thrust belt. The central part of the belt is dominated by a thick monotonous succession of Carboniferous and Permian turbidites, which are intruded with the Kis-Kuel granodiorite pluton. Ore is localized in the apex of the small (about $2 \mathrm{~km}^{2}$ ) cylindrical-shaped Kis-Kuel pluton. The pluton geometry is cylinder-shaped with steep sides, which is important for fluid focusing (Stephens et al., 2004).

The formation of the Verkhoyansk fold-and-thrust metallogenic belt included several stages (Prokopiev et al., 2018):

- Formation of ore fields (sericite): ${ }^{40} \mathrm{Ar} /{ }^{39} \mathrm{Ar}$, plateau at $98.2 \pm 1.1 \mathrm{Ma}$;

- Crystallization of granitic plutons (zircon): U-Pb SHRIMP-II,100.2 $\pm 1.2 \mathrm{Ma}$;

- Formation of dike complexes (zircon): U-Pb SHRIMP-II,102.9 \pm 1.4 and 104.9 \pm 1.4 .

Magmatic contribution to this deposit is significant. Intrusive rocks range from diorite to granodiorite in composition (Supplement 1.2, Fig. 3A) and are exposed to a high-K field on the $\mathrm{Na}_{2} \mathrm{O}+\mathrm{K}_{2} \mathrm{O}$-silica diagram (Fig. 3B); they belong to ilmenite-series granitoids (Fig. 3C). The source region is reflected in the trace element composition, where the

${ }^{1}$ Hereinafter, applications 1.1-1.5 (applications are given in the original edition) can be found at the website: https://escjournal.spbu.ru/article/view/3963/4905. 

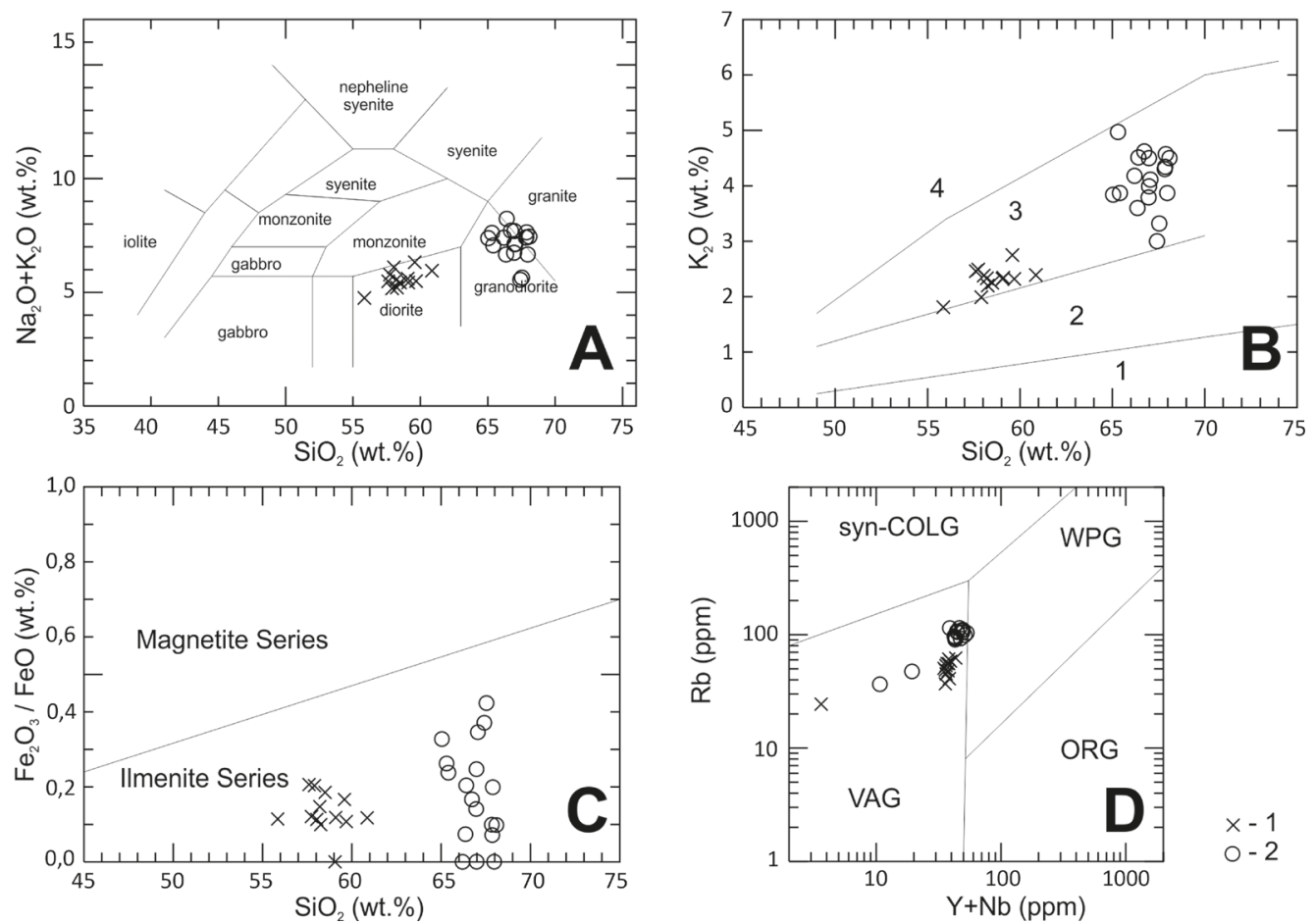

Fig. 3. Variation diagrams for the Kis-Kuel intrusive rocks $(1-$ diorite, $2-$ granodiorite $)$ associated with IOCG mineralization: $\mathrm{A}$. $\mathrm{SiO}_{2}-\mathrm{K}_{2} \mathrm{O}+\mathrm{Na}_{2} \mathrm{O}$ diagram (Cox and Bell, 1979) showing intrusive rocks range from diorite to granodiorite in composition. $\mathrm{B} . \mathrm{SiO}_{2}-\mathrm{K}_{2} \mathrm{O}$ diagram (Peccerillo and Taylor 1976) exposing all rock samples in high-K field (Fields: 1 - Arc Tholeiite Series; 2 - Calc-Alkaline Series; 3 High-K Calc-Alkaline Series; 4 - Shoshonitic Series). C. $\mathrm{SiO}_{2}-\mathrm{Fe}_{2} \mathrm{O}_{3} / \mathrm{FeO}$ diagram (Ishihara, 1977; Ishihara, 1998) showing oxidised-reduced index $\mathrm{Fe}_{2} \mathrm{O}_{3} / \mathrm{FeO}$ with magnetite and ilmenite series. All the Kis-Kuel rock samples belong to the ilmenite series. D. $\mathrm{Y}+\mathrm{Nb}-\mathrm{Rb}$ diagram (Pearce et al., 1984) showing fields for different granite types: syn-COLG - Syn-collisional granite, WPG - within plate granite, VAG volcanic arc granite, ORG - orogenic granite. Kis-Kuel IOCG-associated rocks belong to volcanic arc granite area

Kis-Kuel rocks plot in the volcanic arc granite field on tectonic discrimination diagrams (Fig. 3D).

REE element data are reported in Supplement 1.2. The $\Sigma$ REE is low variable, ranging from $162.73 \mathrm{ppm}$ to $206.04 \mathrm{ppm}$ in diorites and from $238.37 \mathrm{ppm}$ to $388.8 \mathrm{ppm}$ in granodiorites. In general, $\Sigma \mathrm{REE}$ increases with increasing $\mathrm{SiO}_{2}$ and $\mathrm{K}_{2} \mathrm{O}$ contents (Fig. $4 \mathrm{~A}, \mathrm{~B}$ ) for the Kis-Kuel analysed samples. The europium anomaly $\mathrm{Eu} / \mathrm{Eu}^{*}$ ranges from 0.69 to 0.96 in diorites and from 0.44 to 0.6 in granodiorites, with one sample having $\mathrm{Eu} / \mathrm{Eu}^{*}=1.15$.

The rare-earth geochemical system of igneous rocks of the Kis-Kuel intrusion is characterized by behavior close to the CHArge-and-RAdius-Controlled (CHARAC) system $(26<\mathrm{Zr} / \mathrm{Hf}<46$ и $24<\mathrm{Y} / \mathrm{Ho}<34)$ in which the $\mathrm{H} / \mathrm{Ho}-\mathrm{Zr} / \mathrm{Hf}$ ratios of the pair show a distribution close to chondrite ( $\mathrm{Zr} / \mathrm{Hf}-36.6$ andY/Ho - 27.7) (Bau, 1996). The CHARAC system also includes primitive mantle ( $\mathrm{Y} / \mathrm{Ho}-27.74$; $\mathrm{Zr} / \mathrm{Hf}-36.25)$, MORB (Y/Ho 27.72; $\mathrm{Zr} / \mathrm{Hf}-36.10$ ) and $\mathrm{OIB}(\mathrm{Y} / \mathrm{Ho}-27.36 ; \mathrm{Zr} / \mathrm{Hf}-35.90$ ) (Sun and McDonough, 1989). Figure 4C shows minor deviations of the Kis-Kuel rocks from the CHARAC intervals and indicates an unevolved magmatic system. After Sun and McDonough (1989), the 

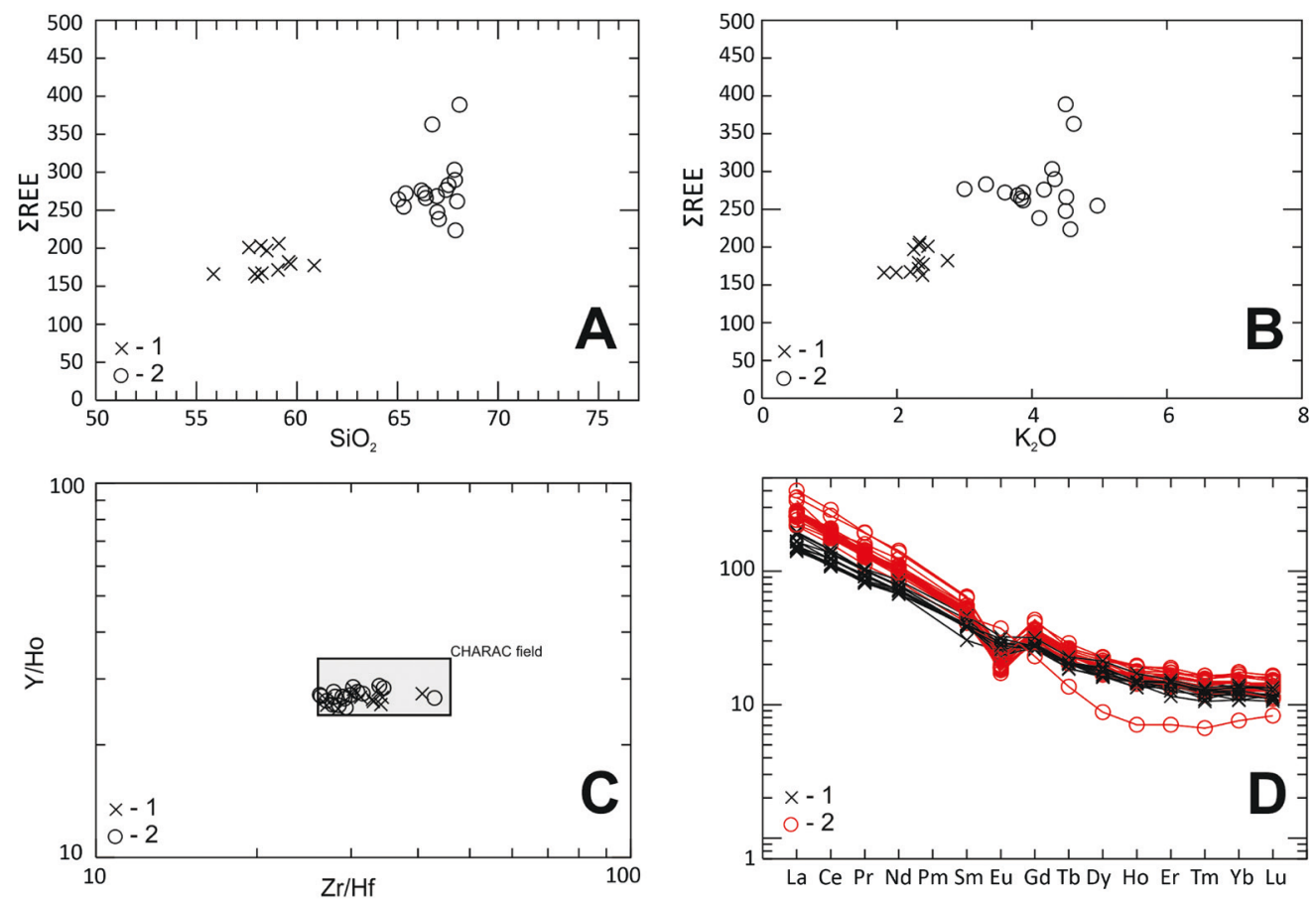

Fig. 4. Variation diagrams for the Kis-Kuel intrusive rocks ( 1 - diorite, $2-$ granodiorite $)$ associated with IOCG mineralization: A. $\Sigma$ REE versus $\mathrm{SiO} 2 \%$ content for the analyzed samples. $\mathrm{B}$. $\Sigma$ REE versus $\mathrm{K}_{2} \mathrm{O} \%$. C. Plot of $\mathrm{Zr} / \mathrm{Hf}$ versus $\mathrm{Y} / \mathrm{Ho}$ for 29 igneous rocks from the Kis-Kuel intrusive showing near-chondritic ratios. The majority of samples plot within the CHARAC field after Bau (1996). D. Chondrite normalized REE diagram for the Kis-Kuel intrusive rocks after Sun and McDonough (1989)

chondrite normalized REE patterns for diorite and granodiorite samples show a light REE enrichment trend and a medium magmatic fractionation process (Fig. 4D).

\section{Ore mineralization}

During 2009 and 2018 fieldwork, high Fe and Au grades in IOCG and Cu-Au porphyry style ores of the Kis-Kuel Breccia Complex (KKBC) were discovered (Fig. 5).

Economic mineralization of $\mathrm{KKBC}$ is localized within the apical zone of a granodiorite-diorite stock and is represented by hematite, goethite, quartz, rare chalcopyrite, arsenopyrite, pyrite, native gold and bismuth (no signs of any ore mineralization were found outside the Kis-Kuel intrusion). KKBC consists of a manto-type irregular-shaped breccia body with arrays of variably mineralized veins and veinlets inside. The KKBC has a complete gradation from hematite-goethite altered granodiorites and more locally - diorites to intensely brecciated and hematite-goethite breccias.

No mining operations were carried out on-site, therefore, the author's resources estimation is given. The total length of the vein zone with gold-bearing samples is about $460 \mathrm{~m}$ long and $2 \mathrm{~m}$ thick. Density $=2.7 \mathrm{t} / \mathrm{m}^{3}$, average gold content $29.07 \mathrm{~g} / \mathrm{t}$, inferred resources for vein about $5 \mathrm{t} \mathrm{Au}(162,500 \mathrm{oz}$ of gold). The surface of gold-bearing stock- 
work is about $7787 \mathrm{~m}^{2}$, density $=2.7 \mathrm{t} / \mathrm{m}^{3}$, the average gold content of $29.07 \mathrm{~g} / \mathrm{t}$, inferred resources of about $30.5 \mathrm{t} \mathrm{Au}(982,500 \mathrm{oz}$ of gold).

1. Iron oxide copper-gold, copper-porphyry with quartz-gold-bismuth-copper veins and sheeted quartz vein arrays are associated with a strong brecciation event and often contain different size fragments of host granodiorites. Rare sulfides are partly oxidized, and small cracks are filled with scorodite, malachite and azurite (Supplement 1.3). Lead-silver veins and ore breccias with additional IOCG mineralization are located both in diorites and in granodiorites. Diorites close to galena veins are usually mineralized with disseminated copper minerals, and thin fractures in it are filled with malachite and azurite (Supplement 1.1C, D).

2. Porphyry copper-gold ore consists of disseminated copper minerals in rocks, veins and breccias and is associated with quartz-molybdenite mineralization (Supplement $1.4 \mathrm{~A}, \mathrm{~B})$. High-grade gold and copper samples from permafrost heavings with iron and copper minerals are strongly oxidized (Supplement $1.4 \mathrm{~A}, \mathrm{~B}$ ). We identified there arthurite $\mathrm{CuFe}_{2}\left(\left(\mathrm{H}_{2} \mathrm{O}\right)_{4}(\mathrm{OH})_{2}\left(\mathrm{AsO}_{4}\right)_{2}\right)$, jarosite $\left(\mathrm{K}_{0.95}\left(\mathrm{H}_{3} \mathrm{O}\right)_{0.05}\right)$ $\mathrm{Fe}_{3}\left(\mathrm{SO}_{4}\right)_{2}(\mathrm{OH})_{6}$ and scorodite $\mathrm{FeAsO}_{4}\left(\mathrm{H}_{2} \mathrm{O}\right)_{2}$ by $\mathrm{x}$-ray phase analysis on a D2 PHASER diffractometer. In the porphyry environment, wall-rock alteration is linked to narrow veins, commonly 0.1 to $5 \mathrm{~cm}$ in width, that typically make up less than 1-5 volume percent of ore (Supplement 1.4C).

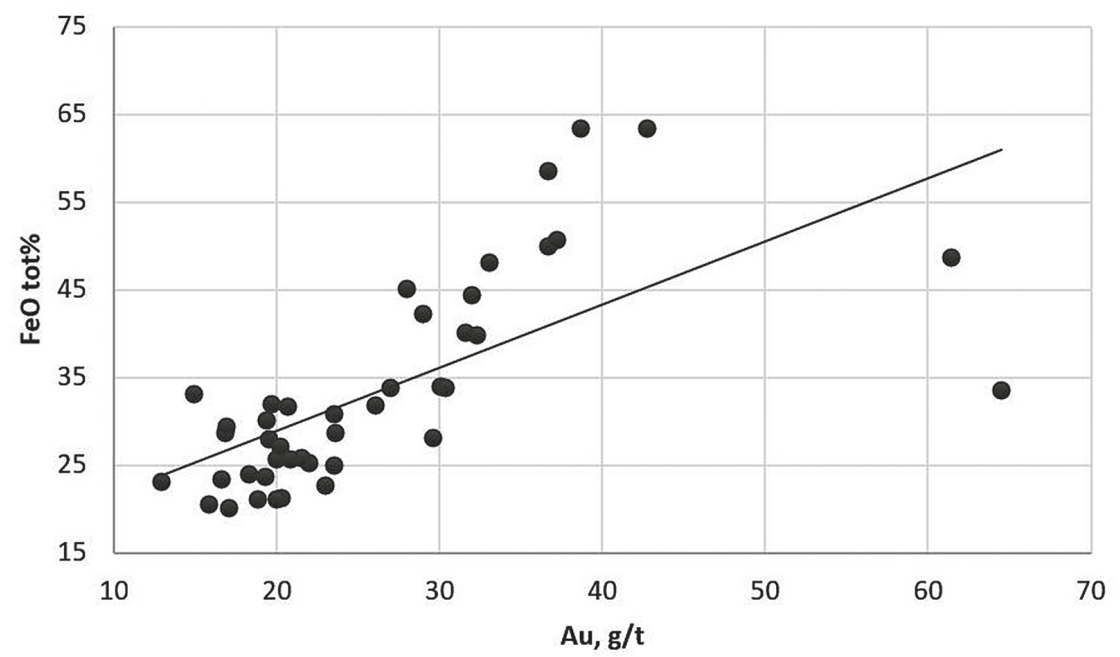

Fig. 5. Correlation between gold grade and $\mathrm{FeO}$ total in IOCG and $\mathrm{Cu}-\mathrm{Au}$ porphyry ore samples (gold was determined by the atomic absorption method on the iCE 3500 spectrometer, checked with the standard GEOSTATS PTY LTD: G908-8 with Au $9.65 \mathrm{~g} / \mathrm{t}$; iron was determined by photometric method on spectrophotometer SF-56). FeO total grade in gold-bearing ore completely corresponds to IOCG ore style

3. Intrusion-hosted sheeted veins with gold-bismuth mineralization in the apex of the Kis-Kuel pluton consist of light-yellow single-stage quartz, $0.5-5 \mathrm{~cm}$ in width with minor sulphides and mica. All of the veins are parallel to the north-south elongate direction of the structural elements such as dikes and shears (Supplement 1.5A, B). Some of the quartz veins include clusters of arsenopyrite (Supplement 1.5C) 
with native gold, bismuth, bismite and neyite (Supplement 1.5D, E). Native bismuth contains a small amount of silver and gold. The admixture of gold and rare telluriumare is also present in neyite (Table) - a typical primary sulfide mineral in porphyry molybdenum deposits (Drummond et al., 1969) and in many intrusion-related gold deposits (Pollard, 2006; Hart, 2007).

Table. Representative microprobe analyses of Au-Bi minerals from sheeted quartz veins, wt. \% (from sample in Supplement 1.5C)

\begin{tabular}{|c|c|c|c|c|c|c|c|c|}
\hline $\mathrm{O}$ & $S$ & $\mathrm{Cu}$ & $\mathrm{Ag}$ & $\mathrm{Au}$ & $\mathrm{Pb}$ & $\mathrm{Bi}$ & $\mathrm{Te}$ & Total \\
\hline \multicolumn{9}{|c|}{ Gold native $(\mathrm{Au})$} \\
\hline & & & 23.32 & 73.87 & & & & 97.19 \\
\hline & & & 22.88 & 76.07 & & & & 98.95 \\
\hline & & & 25.31 & 71.91 & & & & 97.22 \\
\hline & & & 24.77 & 72.36 & & & & 97.13 \\
\hline \multicolumn{9}{|c|}{ Bismuth native (Bi) } \\
\hline & & & 0.8 & 0.66 & & 98.89 & & 100.35 \\
\hline & & & 0.12 & 0.73 & & 98.62 & & 99.47 \\
\hline \multicolumn{9}{|c|}{ Bismite $\left(\mathrm{Bi}_{2} \mathrm{O}_{3}\right)$} \\
\hline 10.26 & & & & & & 89.59 & & 99.85 \\
\hline 10.17 & & & & & & 89.17 & & 99.34 \\
\hline 10.35 & & & & & & 88.85 & & 99.2 \\
\hline 11.77 & & & & & & 88.42 & & 100.19 \\
\hline 14.83 & & & & & & 84.91 & & 99.74 \\
\hline \multicolumn{9}{|c|}{ Neyite $\left(\mathrm{AgCu}_{3} \mathrm{~Pb}_{12.5} \mathrm{Bi}_{13} \mathrm{~S}_{34}\right)$} \\
\hline & 15.77 & 1.75 & 4.33 & & 32.16 & 43.99 & & 98.0 \\
\hline & 16.39 & 3.46 & 4.54 & 0.4 & 36.42 & 38.5 & & 99.71 \\
\hline & 14.6 & 3.02 & 5.07 & 0.03 & 37.43 & 37.93 & & 98.08 \\
\hline & 15.31 & 0.97 & 5.42 & & 38.95 & 37.26 & 1.87 & 99.78 \\
\hline & 15.67 & 0.87 & 5.23 & 1.28 & 40.86 & 36.72 & & 100.63 \\
\hline & 15.17 & 2.16 & 5.2 & 0.97 & 39.16 & 35.18 & & 97.84 \\
\hline
\end{tabular}




\section{Discussion}

Prior to the author's fieldwork in 2009 and 2018 at the Kis-Kuel site, no manifestations of ore mineralization were known. The most interesting finding was that, unlike many ore regions of Eastern Yakutia, the entire ore mineralization is concentrated inside or close to the intrusion. We believe that it was greatly influenced by the emplacement of the Kis-Kuel intrusive body. As follows from the above REE diagrams, the fractionation of the magmatic melt was extremely insignificant. Due to this, a significant part of the iron did not fractionate into high-iron melts, and separated into hydrothermal solutions. Following L Du. et al. (2015), we find that the calc-alkaline evolution trend (Fig. 6) of the Kis-Kuel magmatic rocks influenced the accumulation of iron in the ore. Earlier we were able to confirm this pattern by the example of IOCG manifestations in the basalts of the Sette-Daban ridge (Yakutia, Russia), where significant accumulations of hematite ores with copper and gold were produced within the calc-alkaline trend of basalts (Kostin, 2018). Similarly, the calc-alkaline trend in the evolution of rocks in conjunction with the identified linear ore zones of the IOCG type may indicate the presence in the deep horizons of undetected iron-rich reservoirs (El-Desoky et al., 2015; Chin et al., 2018) with $\mathrm{Fe}$-oxide-Cu-Au ores.

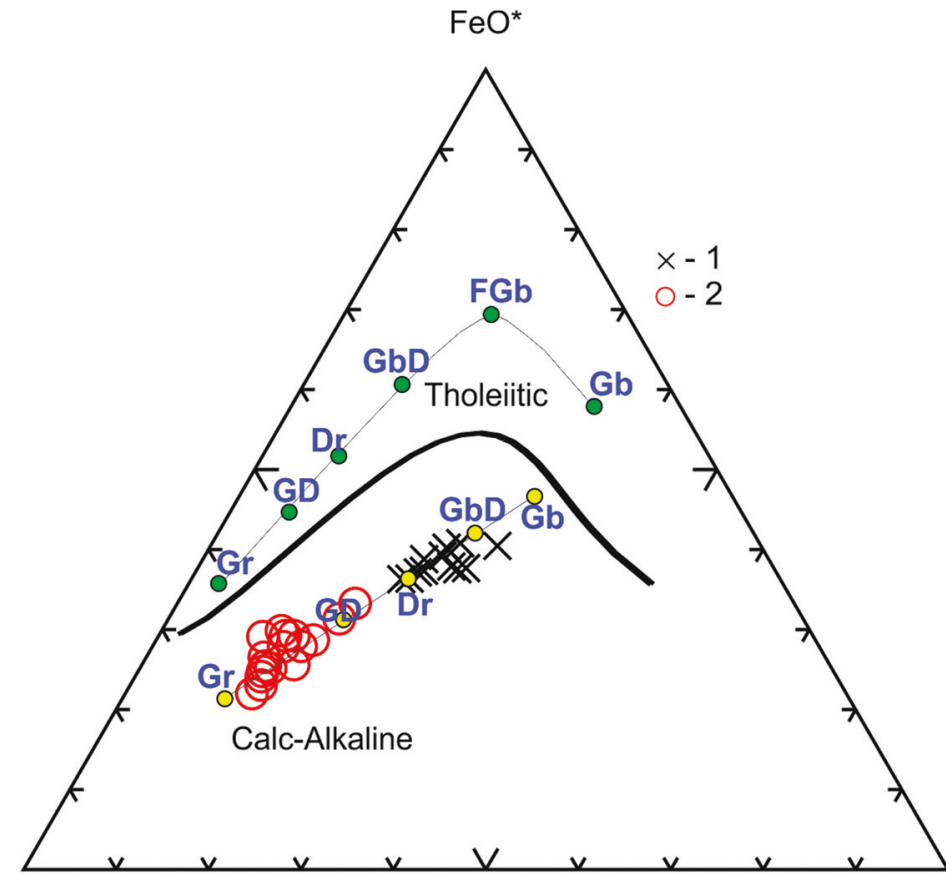

Alk

$\mathrm{MgO}$

Fig. 6. AFM-diagram (Irvine and Baragar, 1971) for the Kis-Kuel intrusive rocks ( 1 - diorite, 2 - granodiorite), showing the relative proportions of the oxides $\mathrm{Na}_{2} \mathrm{O}+\mathrm{K}_{2} \mathrm{O}$ (Alk), $\mathrm{FeO}+\mathrm{Fe}_{2} \mathrm{O}_{3}\left(\mathrm{FeO}^{*}\right)$ and $\mathrm{MgO}$. Green circles showing theoretical composition for tholeiitic, and yellow circles - for calc-alkaline series ( $\mathrm{Gb}$ Gabbro, FGb - Ferro-Gabbro, GbD - Gabbro-Diorite, Dr - Diorite, GD Granodiorite, Gr - Granite) 
Several spatially approximated mineral types of ores were found in the contours of intrusive rocks: $\mathrm{Fe}$-oxide- $\mathrm{Cu}-\mathrm{Au}, \mathrm{Cu}-\mathrm{Au}$-porphyry and associated systems of linear quartz veins with $\mathrm{Au}-\mathrm{Bi}$ mineralization. It is important that in all varieties there are few sulfides; the bulk of the ore is composed of iron oxides. All types of ores are highly gold-bearing and are part of one large ore-magmatic $\mathrm{Cu}-\mathrm{Au}$-porphyry system.

Pollard (2006) and Tornos et al. (2010) described genetic relationships between IOCG and $\mathrm{Cu}$-Au-porphyry systems. Our studies have confirmed this genetic link, for example of the Kis-Kuel intrusion. Gold $\pm \mathrm{Bi}$, As, Mo, Te occurs in: single, sheeted-series and stockwork quartz veins; disseminations in granodiorites and diorites; and as infill in breccias. Base metal contents are highly variable from almost absent to assemblages of $\mathrm{Cu}-\mathrm{Zn}-\mathrm{Pb}$ ores.

After the research, Kis-Kuel is regarded as an intrusion-related gold deposit (IRGD) with a main IOCG and minor Cu-Au-porphyry style of mineralization. Sillitoe (1991) and Thompson et al. (1999) described similar magma types and metal associations (Au, Bi, W, As, Mo, Te and/or Sb) for different IRGD deposit styles.

Now we are only at the beginning stages of research, and there is much work to do. The occurrence of an IOCG deposit in Eastern Yakutia (Russia) requires further research and should be associated with a detailed study of mineral composition of ores and associated magmatism, characterization of alteration facies at a regional to deposit scale, and the study of the mineralogy of gold - an important area of future research.

\section{Funding}

This research was funded by the Diamond and Precious Metal Geology Institute, Siberian Branch of the Russian Academy of Sciences, project number 0381-2019-004.

\section{Acknowledgments}

The author expresses his gratitude to Dr. Louise Corriveau for his constructive comments and excellent suggestions that helped to improve the manuscript. For their support of the idea of studying the Kis-Kuel site and numerous discussions on all aspects of IOCG deposits, I am grateful to my Institute colleagues - Valery Y. Fridovsky, Albert I.Zaitsev, and Maria S. Jelonkina. Larisa T. Galenchikova is thanked for excellent chemical analyses of rocks, Anna S. Vasileva - for gold and iron analyses, Nadejda V.Zajakina and Tatyana I. Vasileva - for x-ray analyses of IOCG ores. Microprobe analyses were provided with the great help of Svetlana K. Popova. Sample preparation for microscope and microprobe studies was carried out by Vladimir Kurchatov.

\section{References}

Bau, M., 1996. Controls on the fractionation of isovalent trace elements in magmatic and aqueous systems: evidence from $\mathrm{Y} / \mathrm{Ho}, \mathrm{Zr} / \mathrm{Hf}$, and lanthanide tetrad effect. Contributions to Mineralogy and Petrology 123 (3), 323-333. https://doi.org/10.1007/s004100050159

Chin, E.J., Shimizu, K., Bybee, G.M., Erdman, M.E., 2018. On the development of the calc-alkaline and tholeiitic magma series: A deep crustal cumulate perspective. Earth and Planetary Science Letters 482, 277-287. https://doi.org/10.1016/j.epsl.2017.11.016 
Chorlton, L. B., 2007. Generalized geology of the world: bedrock domains and major faults in GIS format: a small-scale world geology map with an extended geological attribute database. Geological Survey of Canada, Open File 5529, 1 CD-ROM https://doi.org/10.4095/223767 (Open Access)

Corriveau, L., 2007. Mineral Deposits of Canada: Iron Oxide Copper-Gold Deposits: A Canadian Perspective. In: Goodfellow W.D.ed., Mineral deposits of Canada: A Synthesis of Major Deposit-Types, District Metallogeny, the Evolution of Geological Provinces, and Exploration Method. Geological Association of Canada, Mineral Deposits Division, Special Publication 5, 307-328.

Corriveau, L., Potter, E. G., Montreuil, J.F., Blein, O., Ehrig, K., De Toni, A., 2018. Iron-oxide and alkalicalcic alteration ore systems and their polymetallic IOA, IOCG, skarn, albitite-hosted $\mathrm{U} \pm \mathrm{Au} \pm \mathrm{Co}$, and affiliated deposits. A short course series. Part 2: Overview of deposit types, distribution, ages, settings, alteration facies, and ore deposit models: Geological Survey of Canada, Scientific Presentation 81. https://doi.org/10.4095/306560

Cox, K. G., Bell, J.D., Pankhurst, R. J., 1979. The Interpretation of Igneous Rocks. Allen and Unwin, London. https://doi.org/10.1007/978-94-017-3373-1

Drummond, A.D., Trotter, J., Thompson, R. M., Gower, J. A., 1969. Neyite, a new sulphosalt from Alice Arm, British Columbia. The Canadian Mineralogist 10 (1), 90-96.

Du, L., Yang, C., Derek, A. W., Allen P. N. Lu, Z., Zhao, L., Wang, W., Song, H., Wan, Y., Ren, L., Geng. Y., 2015. Petrogenesis and tectonic implications of the iron-rich tholeiitic basalts in the Hutuo Group of the Wutai Mountains, Central Trans-North China Orogen. Precambrian Research 271, 225-242. https:// doi.org/10.1016/j.precamres.2015.10.008

El-Desoky, H. M., Khalil, A. E., Afifi, A. A., 2015. Geochemical and petrological characteristics of the high-Fe basalts from the Northern Eastern Desert, Egypt: Abrupt transition from tholeiitic to mildly alkaline flow-derived basalts. Nature and Science 13 (6), 109-132.

Hart, C.J.R., 2007. Reduced intrusion-related gold systems. In: Goodfellow, W.D., (Ed.), Mineral deposits of Canada: A Synthesis of Major Deposit Types, District Metallogeny, the Evolution of Geological Provinces, and Exploration Methods. Geological Association of Canada, Mineral Deposits Division 5, 95-112.

Irvine, T.N., Baragar, W.R., 1971. A guide to the chemical classification of the common volcanic rocks. Canadian Journal of Earth Sciences 8, 523-548. https://doi.org/10.1139/e71-055

Ishihara, S., 1977. The magnetite-series and ilmenite-series granitic rocks. Mining Geology 27, 293-305. https://doi.org/10.11456/shigenchishitsu1951.27.293

Ishihara, S., 1998. Granitoid series and mineralization in the Circum-Pacific Phanerozoic granitic belts. Resource Geology 48(4), 219-224. https://doi.org/10.1111/j.1751-3928.1998.tb00019.x

Kostin, A. V., 2012. Iron-Oxide Cu-Au (IOCG) Mineralizing Systems: Eastern Yakutia Perspective. Journal of Environmental Science and Engineering 9, 1045-1053. [View at publisher]

Kostin, A. V., Vedyaev, A. Y., Rafat, G., 2014. Iron oxide Cu-Au (IOCG) mineralizing systems: an example from northeastern Russia. The Journal of the Southern African Institute of Mining and Metallurgy 114, 645-650. [View at publisher]

Kostin, A. V., Zaitsev, A.I., Shoshin, V.V., Ganeev, A.Sh., Lobanov, S. P., 1997a. Silver province in the West Verkhoyansk Area. YaNC SO RAN, Yakytsk. (In Russian)

Kostin, A. V., Lobanov, S. P., Shoshin, V. V., 1997b. Economic types of silver deposits in northeastern Yakutia. Otechestvennaia Geologiia 1, 8-16. (In Russian)

Kostin, A. V., 2002. On polygenic nature of gold and silver deposits on a frontal part of the Verkhoyansk folded belt. Otechestvennaia Geologiia 5, 8-11. (In Russian)

Kostin, A. V., 2003. Zoning of Arkachan Au-Cu deposit (Western Verkhoyansk area). Otechestvennaia Geologiia 6, 24-29. [CrossRef] (In Russian)

Kostin, A. V., 2018. The manifestation Rosomakha - high-productive type of Fe-oxide-Cu-Au mineralization in basalts of the Sette-Daban ridge. Advances in Current Natural Sciences 11, 115-121. DOI: 10.17513/ use.36914

Metallogenesis and tectonics of northeast Asia, 2010 / Nokleberg, W.J.(Ed.), Professional Paper 1765. U.S. Geological Survey.

Parfenov, L. M., Prokopiev, A. V., Gaiduk, V. V., 1995. Cretaceous frontal thrusts of the Verkhoyansk fold belt, eastern Siberia. Tectonics 14 (2), 342-358. https://doi.org/10.1029/94TC03088

Pearce, J.A., Harris, N.B.W., Tindle, A. G., 1984. Trace element discrimination diagrams for the tectonic interpretation of granitic rocks. Journal of Petrology 25 (4), 956-983. https://doi.org/10.1093/ petrology/25.4.956 
Peccerillo, A., Taylor, S. R., 1976. Geochemistry of Eocene calc-alkaline volcanic rocks from the Kastamonu area, Northern Turkey. Contributions to Mineralogy and Petrology 58 (1), 63-81. https://doi. org/10.1007/BF00384745

Pollard, P. J., 2000. Evidence of a magmatic fluid and metal source for Fe-oxide $\mathrm{Cu}$-Au mineralization. In: Porter, T.M.(Ed.), Hydrothermal iron oxide copper-gold and related deposits: a global perspective. PGC Publishing, Adelaide 1, 27-41.

Pollard, P. J., 2006. An intrusion-related origin for $\mathrm{Cu}-\mathrm{Au}$ mineralization in iron oxide-copper-gold (IOCG) provinces. Mineralium Deposita 41 (2), 179-187. https://doi.org/10.1007/s00126-006-0054-x

Porter, T.M., 2000. Hydrothermal iron-oxide copper-gold \& related ore deposits. In: Porter, T.M.(Ed.), Hydrothermal iron oxide copper-gold and related deposits: a global perspective. PGC Publishing, Adelaide 1, 3-5.

Prokopiev, A. V., Khudoley, A. K., Koroleva, O. V., Kazakova, G. G., Lokhov, D. K., Malyshev, S. V., Zaitsev, A. I., Roev, S.P., Sergeev, S.A., Berezhnaya, N.G., Vasiliev, D.A., 2016. The Early Cambrian bimodal magmatism in the northeastern Siberian Craton. Russian Geology and Geophysics 57 (1), 155-175. https://doi.org/10.1016/j.rgg.2016.01.011

Prokopiev, A.V., Borisenko, A.S., Gamyanin, G.N., Pavlova, G.G., Fridovsky, V.Yu., Kondrat'eva, L.A., Anisimova, G.S., Trunilina, V.A., Ivanov, A.I., Travin, A.V., Koroleva, O.V., Vasiliev, D.A., Ponomarchuk, A. V., 2018. Age constraints and tectonic settings of metallogenic and magmatic events in the Verkhoyansk - Kolyma folded area. Russian Geology and Geophysics 59, 1237-1253. https:// doi.org/10.1016/j.rgg.2018.09.004

Richards, J.F., Lopez, G.P., Zhu, Jing-Jing, Creaser, R.A., Locock, A.J., Mumim, A.H., 2017. Contrasting tectonic settings and sulfur contents of magmas associated with Cretaceous Porphyry $\mathrm{Cu}-\mathrm{Mo}$ and Intrusion-Related Iron Oxide $\mathrm{Cu}-\mathrm{Au}$ deposits in Northern Chile. Economic Geology 112 (2), 295318. http://dx.doi.org/10.2113/econgeo.112.2.295

Sillitoe, R. H., 1991. Intrusion-related gold deposits. In: Gold metallogeny and exploration. Springer, Boston, 165-209. https://doi.org/10.1007/978-1-4613-0497-5_6

Stephens, J.R., Mair, J.L., Oliver, N.H.S., Hart, C.J.R., Baker, T., Blenkinsop, T.G., Vearncombe, J.R., Reddy, S. M., 2004. Structural and mechanical controls on intrusion-related deposits of the Tombstone gold belt, Yukon, Canada, with comparisons to other vein-hosted ore-deposit types. Journal of Structural Geology 26, 1025-1041. https://doi.org/10.1016/j.jsg.2003.11.008

Sun, S. S., McDonough, W.F., 1989. Chemical and isotopic systematics of oceanic basalts: implications for mantle composition and processes. Geological Society, London, Special Publications 42 (1), 313-345. http://dx.doi.org/10.1144/GSL.SP. 1989.042.01.19

Tectonics, Geodynamics, and Metallogeny of the Sakha Republic (Yakutia) Territory, 2001 / Parfenov, L. M., Kuzmin, M.I.(Eds), MAIK Nauka/Interperiodik, Moscow. (In Russian)

Thompson, J. F. H., Sillitoe, R. H., Baker, T., Lang, J.R., Mortensen, J. K., 1999. Intrusion-related gold deposits associated with tungsten-tin provinces. Mineralium Deposita 34, 323-334. https://doi.org/10.1007/ s001260050207

Tornos, F., Velasco, F., Barra, F., Morata, D., 2010. The Tropezón Cu-Mo-(Au) deposit, Northern Chile: the missing link between IOCG and porphyry copper systems. Mineralium Deposita 45 (4), 313-321. https://doi.org/10.1007/s00126-010-0277-8

Williams, P. J., Barton, M. D., Johnson, D. A., Fontboté, L., de Haller, A., Mark, G., Oliver, N. H. S., Marschik, R., 2005. Iron-oxide copper-gold deposits: geology, space-time distribution, and possible modes of origin. Economic Geology 100, 371-405.

Received: January 27, 2019

Accepted: October 1, 2019

Contact information:

Aleksey V.Kostin - kostinav57@gmail.com 


\title{
Кис-Кюельское $\mathrm{Fe}-\mathrm{Cu}-\mathrm{Au} \pm$ (Ag, Mo, Bi) месторождение в Восточной Якутии (Россия): связь между железо-оксидными медно-золотыми и связанными с интрузиями золоторудными системами
}

\author{
A. В. Костин \\ Институт геологии алмаза и благородных металлов \\ Сибирского отделения Российской академии наук, \\ Российская Федерация, 677000, Якутск, пр. Ленина, 39
}

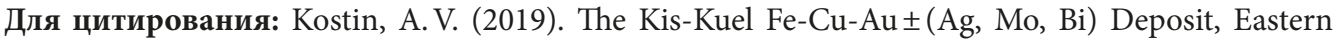
Yakutia (Russia) - A Link between Iron Oxide Copper-Gold and Intrusion Related Gold Systems. Вестник Санкт-Петербургского университета. Науки о Земле, 64 (4), 516-529.

https://doi.org/10.21638/spbu07.2019.401

Класс железо-оксидных медно-золотых (IOCG) включает в себя генетически слабо связанные месторождения с совокупностью общих признаков. Одно из них локализовано в Кис-Кюельском интрузиве (Восточная Якутия, Россия) и характеризуется широким спектром минеральных парагенезисов, имеющих прямую генетическую связь со становлением интрузива. Руды имеют общие черты месторождений IOCGтипа - обилие оксидов железа и небольшое количество сульфидов. Рудовмещающие интрузивные породы по составу варьируются от диорита до гранодиорита. Редкоземельная геохимическая система магматических пород интрузива Кис-Кюель характеризуется поведением, близким к CHARge (заряд)-и-Radius (радиус)-контролируемой системе CHARAC $(26<\mathrm{Zr} / \mathrm{Hf}<46$ и $24<\mathrm{Y} / \mathrm{Ho}<34)$, в которой отношения Y/Но $-\mathrm{Zr}$ / $\mathrm{Hf}$ пары показывают распределение, близкое к хондриту ( $\mathrm{Zr} / \mathrm{Hf}-36,6$ и Y/Ho - 27,7). Незначительные отклонения пород от интервалов CHARAC указывают на низкий уровень эволюции магматической системы. Рудная минерализация была обнаружена в кровле интрузивного массива и включает несколько минеральных типов. Железо-оксидный медно-золотой и медно-порфировый представлены брекчиями в ореоле ороговикованных и интрузивных пород с FeOX (13,58-63,24\%); $\mathrm{Cu}(0-3,57 \%) ; \mathrm{Au}(12,93-$ 64,48 г/т); Ag (2,7-830 г/т). Ассоциирущие с IOCG кварц-гематит-галенитовые жилы содержат Ag (22,4-3680 г/т); Cu (0,014-0,534\%); Pb (0,1-81,63\%). Массивы листоватых железистых кварцевых жил с арсенопиритом, самородным золотом и висмутом, а также Ag-Bi-сульфосолями содержат Au (0,15-4,6 г/т); $\mathrm{Ag}$ (20,6-196 г/т); Cu (0,048-0,24 \%); $\mathrm{Pb}(0,3-3,73 \%)$. Статья посвящена Кис-Кюельскому месторождению, связанному с диорит-гранодиоритовым интрузивом в Восточной Якутии (Россия). Оно рассматривается как связанное с интрузией (IRGD) комплексное месторождение золота, в котором основным компонентом являются руды IOCG-типа и второстепенным - $\mathrm{Cu}$ - $\mathrm{Au}$ порфирового.

Ключевые слова: Восточная Якутия, Кис-Кюельский рудный узел, железо-оксидное медно-золотое месторождение, связанное с интрузивом, поиск золота.

Статья поступила в редакцию 27 января 2019 г.

Статья рекомендована в печать 1 октября 2019 г.

Контактная информация:

Костин Алексей Валентинович - kostinav57@gmail.com 